\title{
Studi Komparasi Hasil Belajar Biologi dengan Pembelajaran INSTAD (Inquiry-STAD) dan Pembelajaran Inkuiri Terbimbing (Guided Inquiry) pada Siswa Kelas X SMA Negeri Gondangrejo Tahun Pelajaran 2012/2013
}

\author{
Study Comparative on Biology Learning Achievement Using InSTAD (Inquiry-STAD) \\ and Guided Inquiry Learning Models in the X Graders of SMA Negeri Gondangrejo \\ in the School Year of 2012/2013
}

\author{
Dina Dyah Saputri, Harlita, Puguh Karyanto \\ Pendidikan Biologi FKIP Universitas Sebelas Maret \\ Email: chim_ah@yahoo.com
}

Diterima 5 Agustus 2013, disetujui 6 September 2013

\begin{abstract}
This research aimed to find out the effect of inquiry-STAD (InSTAD) learning compared with that of the guided inquiry on the biology learning achievement of the $\mathrm{X}$ graders of SMA Negeri Gondangrejo in the school year of 2012/2013.This study was a quasi-experiment research. The research design was Post-Test only with Nonequivalent Group using experiment 1 class (InSTAD strategy) and experiment 2 (guided inquiry strategy application). The population of research was all X graders of SMA Negeri Gondangrejo in the school year of 2012/2013. The sampling technique used was cluster sampling and two classes were taken as experiment 1 and experiment 2 classes. Techniques of collecting data used were multiple-choice test, observation sheet, and school document. The hypothesis testing was done using t-test. The conclusion of this research were have not differences result between InSTAD and Guided Inquiry learning toward student's cognitive achievement in studying biology of SMA Negeri Gondangrejo and have differences result between InSTAD and Guided Inquiry learning toward student's afective and psycomotor achievement in studying biology of SMA Negeri Gondangrejo. With this research is expected to have a discourse teachers and new knowledge and be able to apply this learning to improve science process skills in students so that the nature of biology can be realized students working scientifically.
\end{abstract}

Key Words: INSTAD Learning , Guided Inquiry Learning, Biologi Learning Achievement

\section{Pendahuluan}

Biologi merupakan bagian dari Ilmu Pengetahuan Alam atau Sains yang mempelajari tentang makhluk hidup dan lingkungannya. Rustaman (2005) menyatakan dalam pembelajaran sains siswa tidak hanya mempelajari produk saja sebagai hasil akhir dari belajar sains, tetapi juga harus mempelajari aspek proses, sikap, dan teknologi agar siswa dapat benar-benar memahami sains secara utuh dan menyeluruh. Pembelajaran yang menyeluruh diharapkan dapat memberikan perubahan tingkah laku sebagai bentuk hasil belajar.

Sudjana (2010) menyatakan bahwa dalam rumusan tujuan sistem pendidikan nasional, baik tujuan kurikuler maupun tujuan instruksional, menggunakan klasifikasi hasil belajar dari Benyamin Bloom yang secara garis besar membaginya menjadi tiga ranah, yaitu ranah kognitif, ranah afektif, dan 
ranah psikomotor. Hal ini didukung oleh pendapat Adeyemi (2009) yang menyatakan bahwa ranah kognitif, afektif dan psikomotorik saling berkaitan antara satu dengan yang lainnya dan tidak dapat terpisahkan karena merupakan komponen penyusun sains. Salah satu hal yang mempengaruhi kegiatan pembelajaran adalah strategi, pendekatan, atau model yang diterapkan guru ketika mengajar. Strategi pembelajaran merupakan salah satu komponen penting yang harus dikuasai oleh guru dan siswa dalam melaksanakan pembelajaran. Strategi pembelajaran biologi yang dapat memberikan perubahan tingkah laku sebagai bentuk hasil belajar diantaranya Inkuiri Terbimbing (Guided Inquiry). Inkuiri terbimbing yaitu inkuiri dimana guru membimbing siswa melakukan kegiatan dengan memberi pertanyaan awal dan mengarahkan pada suatu diskusi. Guru berperan aktif dalam menentukan permasalahan dan tahap-tahap pemecahannya. Siswa akan belajar dengan bantuan bimbingan dan petunjuk dari guru hingga siswa dapat memahami konsep-konsep pelajaran (Wulanningsih, 2012). Strategi pembelajaran inkuiri terbimbing di rasa lebih tepat untuk digunakan dalam pembelajaran di SMA karena tingkat berfikir siswa yang masih memerlukan bimbingan dan belum dapat dibiarkan seutuhnya berfikir sendiri (Yager, 2010).

Hanafiah dan Suhana (2009), kelebihan pembelajaran inkuiri yaitu membantu siswa mengembangkan penguasaan keterampilan dalam proses kognitif, siswa memperoleh pengetahuan secara individual sehingga dapat dimengerti dan mengendap dalam pikirannya, membangkitkan motivasi siswa untuk belajar lebih giat, dan menambah kepercayaan diri dengan proses menemukan sendiri karena pembelajaran berpusat pada siswa dengan peran guru sangat terbatas. Kelemahannya adalah siswa harus memiliki kesiapan dan kematangan mental, siswa harus berani dan berkeinginan untuk mengetahui keadaan sekitarnya dengan baik, keadaan kelas yang jumlah siswanya terlalu banyak maka tidak akan mencapai hasil yang memuaskan, dan kritik bahwa inkuiri terlalu mementingkan proses pengertian saja dan kurang memperhatikan perkembangan sikap siswa (Hanafiah dan Suhana, 2009).

Pembelajaran inkuiri terbimbing adalah model inkuiri dimana guru membimbing siswa melakukan kegiatan dengan memberi pertanyaan awal dan mengarahkan pada suatu diskusi. Pembelajaran Inkuiri Terbimbing berbasis konteks masalah, menentukan permasalahan dan tahap-tahap 
pemecahannya (Abdelraheem dan Asan, 2006).

Pembelajaran inkuiri terbimbing, siswa belajar dengan beorientasi pada bimbingan dan petunjuk dari guru hingga siswa dapat memahami konsep-konsep pelajaran. Siswa akan dihadapkan pada tugas-tugas yang relevan untuk diselesaikan baik melalui diskusi kelompok maupun secara individual agar mampu menyelidiki dan menyelesaikan suatu masalah dan menarik suatu kesimpulan secara mandiri (Crawford, 2007).

Model pembelajaran lainnya adalah Inquiry-STAD (InSTAD ). Pembelajaran ini mengintegrasikan pembelajaran Inkuiri dan kooperatif STAD di mana perpaduan antar keduanya akan menghasilkan sintaks yang dapat membimbing siswa untuk melakukan penemuan-penemuan konsep baru namun juga tidak melupakan kegiatan interaksi dengan siswa lain di dalam kelompoknya. Penerapan pembelajaran InSTAD dapat bermakna di dalam pembelajaran biologi di kelas karena siswa belajar dengan inkuiri di dalam kelompok yang kooperatif. Siswa menjadi terbiasa melakukan penemuanpenemuan dan melatih sikap ilmiah serta dapat berinteraksi dengan siswa lain dalam kegiatan pembelajaran (Sidiq, 2012).
Model pembelajaran InSTAD yang merupakan perpaduan sintaks antara model kooperatif tipe STAD dengan sintak inkuiri terbimbing. Sebagian besar sintak inkuiri dimasukkan dalam tahap kerja kelompok dalam sintak pembelajaran STAD, sedangkan sebelum tahap evaluasi individual dan penghargaan kelompok, model pembelajaran STAD dimasukkan tahap pengulangan pembelajaran inkuiri. Dengan demikian strategi pembelajaran InSTAD dapat dikatakan sebagai kegiatan inkuiri dalam kerja kelompok (Prayitno, 2010).

Kombinasi inkuiri dan STAD juga dinilai baik karena dapat meningkatkan proses bejalar dalam kelompok dan akan menimbulkan lingkungan yang positif dimana siswa bekerjasama dalam satu kelompok untuk menyelesaikan masalah sehingga muncul interaksi antarsiswa untuk menemukan solusi masalah yang ditemukan selama proses pembelajaran (Hanson, 2005). Kegiatan inkuiri secara berkelompok dalam mencari solusi masalah pembelajaran akan berpengaruh kepada hasil belajar siswa, karena dalam kegiatan tersebut siswa dituntut untuk berpikir secara analistis, evaluatif, dan kreatif serta bersosialisasi dengan teman dalam satu keompok. Selain hal tersebut siswa juga dapat mengembangkan kemampuan berpikir dalam membangun sebuah 
konsep. Berdasarkan paparan di atas dapat dilihat jika kedua pembelajaran tersebut dapat membimbing siswa menemukan konsepkonsep baru dengan sendirinya. Pembelajaran tersebut dapat memberikan pengaruh pada hasil belajar biologi siswa, sehingga output yang diharapkan dari pembelajaran biologi yang berorientasi pada kegiatan berproses ilmiah dapat tercapai.

Penelitian bertujuan untuk mengetahui perbedaan hasil dari penerapan pembelajaran InSTAD dan pembelajaran Inkuiri terbimbing terhadap hasil belajar biologi siswa Kelas X SMA Negeri Gondangrejo Tahun Pelajaran 2012/2013.

\section{Metode Penelitian}

Penelitian ini termasuk kuasi eksperimen dengan pendekatan kuantitatif. Desain penelitian adalah posttest only non equivalent group design dengan menggunakan kelas eksperimen 1 (penerapan pembelajaran InSTAD) dan kelas eksperimen 2 (pembelajaran Inkuiri Terbimbing).

Populasi dalam penelitian ini adalah seluruh siswa kelas X SMA Negeri Gondangrejo. Teknik pengambilan sampel dengan cluster sampling, sehingga terpilih kelas X2 sebagai kelas eksperimen 1 dan kelas X3 sebagai kelas eksperimen 2.

Variabel bebas berupa pembelajaran InSTAD dan Inkuiri Terbimbing dan variabel terikat adalah hasil belajar biologi siswa yang mencakup ranah kognitif, afektif, dan psikomotorik. Teknik pengumpulan data yang digunakan dalam penelitian ini adalah dokumentasi, tes dan observasi. Metode dokumentasi pada penelitian ini berupa dokumen hasil belajar selama satu semester dengan nilai asli sebagai bahan acuannya yang digunakan untuk mengetahui keseimbangan kemampuan awal siswa berdasarkan nilai hasil belajar biologi pada populasi penelitian. Metode tes digunakan untuk mengambil data hasil belajar ranah kognitif. Metode observasi dalam penelitian ini digunakan untuk mengukur hasil belajar ranah psikomotorik, ranah afektif dan keterlaksanaan sintaks pembelajaran.

Tes uji coba pada instrumen penelitian dilakukan untuk mengetahui validitas produk moment, reliabilitas, daya beda, dan taraf kesukaran. Selain validasi produk moment, instrumen juga divalidasi konstruk oleh ahli.

Analisis data pada penelitian dengan menggunakan uji $t$. Sebelumnya dilakukan uji normalitas menggunakan uji KolmogorovSmirnov dan uji homogenitas dengan uji Levene's.

\section{Hasil dan Pembahasan}

Data penelitian berupa nilai postes hasil belajar biologi. Hasil belajar biologi meliputi ranah kognitif, psikomotor, dan 
afektif. Data postes dianalisis dengan uji-t untuk mengetahui perbedaan hasil dari penerapan pembelajaran InSTAD dan Inkuiri Terbimbing terhadap hasil belajar biologi siswa.

\section{Uji Hipotesis}

Hasil belajar merupakan kesatuan dari tiga ranah yang saling mempengaruhi dan tidak dapat dipisahkan.

\section{Hasil Belajar Ranah Kognitif}

Hasil analisis ada tidaknya perbedaan hasil dari penerapan pembelajaran InSTAD (Inquiry-STAD) dan Inkuiri Terbimbing (Guided Inquiry) terhadap hasil belajar biologi ranah kognitif menggunakan uji $\mathrm{t}$ (Tabel 1).

Tabel 1. Hasil Uji Hipotesis Penerapan pembelajaran InSTAD dan Inkuiri Terbimbing terhadap Hasil Belajar Kognitif

\begin{tabular}{llllll}
\hline $\begin{array}{l}\text { Hasil } \\
\text { Belajar }\end{array}$ & $\mathbf{t}$ & df & Sig & $\mathbf{t}_{(0.25,64)}$ & $\begin{array}{l}\text { Keputu } \\
\text { san Uji }\end{array}$ \\
\hline Kognitif & 0.174 & 61 & 0.863 & 1.999 & $\begin{array}{l}\mathrm{H}_{0} \\
\text { diterima }\end{array}$ \\
\hline
\end{tabular}

Hasil keputusan uji $(s i g)>0,050$ dan nilai $t_{h i t u n g}<t_{(\alpha, d f)}$ sehingga $H_{0}$ diterima. Berdasarkan pada hasil tersebut dapat diketahui bahwa tidak terdapat perbedaan hasil penerapan pembelajaran Inquiry STAD (InSTAD ) dan pembelajaran Inkuiri Terbimbing (Guided Inquiry) terhadap hasil belajar biologi siswa pada ranah kognitif. Hal ini disebabkan karena seluruh siswa baik pada kelas eksperimen 1 maupun eksperimen 2 dapat mengikuti pembelajaran dengan baik. Hasil tersebut sejalan dengan penelitian yang dilakukan oleh Nugroho (2012) yang berjudul Pembelajaran IPA dengan Metode Inkuiri Terbimbing Menggunakan Laboratorium Riil dan Virtuil Ditinjau dari Kemampuan Memori dan Gaya Belajar Siswa menunjukkan hasil uji hipotesis diketahui bahwa $\mathrm{H}_{0}$ diterima pada hasil belajar ranah kognitif. Hal ini berarti tidak terdapat interaksi antara gaya belajar dengan kemampuan memori siswa. Dari hasil pengamatan menunjukkan siswa yang memiliki kemampuan memori tinggi dan rendah serta gaya belajar visual maupun kinestetik sama-sama dapat mengikuti pembelajaran dengan baik.

Nilai rata-rata 70,06 pada kelas eksperimen 1 dengan ketuntasan mencapai 53,12\% dan 70,32 pada kelas eksperimen 2 dengan ketuntasan mencapai 48,39\%. Hasil belajar kognitif pada penelitian ini diperoleh melalui tes tertulis dengan soal berupa pilihan ganda sebanyak 40 butir soal. Siswa banyak diberi kesempatan untuk mengembangkan kemampuan kognitifnya pada pembeljaran inkuiri, terlihat dari setiap tahapan model pembelajaran inkuiri dapat digali pemahaman dan penemuan konsep siswa (Suswandi, 2012). Pembelajaran penemuan tersebut 
relevan dengan teori konstruktivisme. Model pembelajaran inkuiri dilandasi oleh teori konstruktivisme yang menekankan pada pengembangan konsep dalam struktur kognitifnya secara mandiri oleh siswa (Poedjiadi, 2007).

\section{Hasil Belajar Ranah Afektif}

Hasil analisis ada tidaknya perbedaan hasil dari penerapan pembelajaran InSTAD (Inquiry-STAD) dan Inkuiri Terbimbing (Guided Inquiry) terhadap hasil belajar biologi ranah afektif menggunakan uji $\mathrm{t}$ (Tabel 2).

Tabel 2. Hasil Uji Hipotesis Penerapan pembelajaran InSTAD dan Inkuiri Terbimbing terhadap Hasil Belajar Afektif

\begin{tabular}{llllll}
\hline $\begin{array}{l}\text { Hasil } \\
\text { Belajar }\end{array}$ & $\mathbf{t}$ & df & Sig & $\mathbf{t}_{(\mathbf{0 . 2 5}, \mathbf{6 4})}$ & $\begin{array}{l}\text { Keputu } \\
\text { san Uji }\end{array}$ \\
\hline Afektif & 6.196 & 61 & 0.000 & 1.999 & $\begin{array}{l}\mathrm{H}_{0} \\
\text { ditolak }\end{array}$ \\
\hline
\end{tabular}

Hasil keputusan uji (sig) $<0,050$ dan nilai $t_{\text {hitung }}>\mathrm{t}_{(\alpha, \text { df })}$ sehingga $\mathrm{H}_{0}$ ditolak, hal ini berarti perolehan rata-rata nilai afektif antara kelompok eksperimen 1 dengan kelompok eksperimen 2 berbeda nyata. Kelompok eksperimen 1 dan eksperimen 2 memiliki signifikansi rata-rata nilai afektif. Rata-rata nilai afektif siswa kelompok eksperimen 2 lebih tinggi daripada siswa kelompok eksperimen 1. Berdasarkan pada perbedaan nilai rata-rata tersebut dapat diketahui bahwa hasil belajar biologi siswa pada ranah afektif dengan penerapan pembelajaran Inkuiri Terbimbing (Guided Inquiry) lebih baik dibandingkan dengan penerapan pembelajaran Inquiry - STAD (InSTAD).

Nilai rata-rata afektif kelas eksperimen 2 dengan penerapan pembelajaran inkuiri terbimbing lebih tinggi yaitu 86,19 dengan ketuntasan siswa mencapai 100\% dibandingkan dengan kelas eksperimen 1 melalui penerapan pembelajaran InSTAD yaitu 76,56 dengan ketuntasan siswa sebanyak 90,6\% siswa (29 siswa). Hal ini disebabkan karena dalam pembelajaran inkuiri terbimbing, guru lebih banyak memberikan bimbingan ketika pembelajaran berlangsung dibandingkan pada pembelajaran InSTAD . Pendapat tersebut sejalan dengan pernyataan Amien (1987) yang menyatakan bahwa guru memiliki peran penting untuk menyediakan kesempatan bimbingan atau petunjuk yang cukup luas kepada siswa. Dikatakan pula bahwa pembelajaran inkuiri terbimbing merupakan tahap awal sebelum siswa diberikan model pembelajaran inkuiri sesungguhnya. Pada penerapan pembelajaran inkuiri terbimbing siswa lebih aktif, memiliki rasa tanggung jawab untuk memecahkan masalah secara mandiri pada materi pelajaran keanekaragaman hayati.

Indikator afektif dalam pembelajaran IPA merupakan sikap yang diharapkan saat 
dan setelah siswa melakukan proses pembelajaran yang berkaitan dengan sikap ilmiah. Rustaman (2005) menyatakan dalam pembelajaran sains tidak hanya menghasilkan produk dan proses, tetapi juga sikap.

Hasil belajar afektif pada penelitian ini diperoleh melalui lembar observasi. Penilaian melalui lembar observasi oleh observer diharapkan mampu mengukur afektif siswa secara eksternal. Penilaian sikap ilmiah ranah afektif pada pembelajaran InSTAD antara lain tanggung jawab, teliti, jujur, disiplin, menghargai pendapat, dan bekerja sama. Sedangkan penilaian sikap ilmiah ranah afektif pada pembelajaran inkuiri terbimbing meliputi tanggung jawab, teliti, jujur, disiplin, menghargai pendapat, dan bekerja sama. Pembelajaran inkuiri menuntut siswa untuk berpikir kritis dalam memecahkan masalah. Hal ini terlihat melalui kegiatan siswa dalam merumuskan masalah, menguji hipotesis, merancang percobaan, melakukan eksperimen hingga membuat kesimpulan sehingga siswa dapat menemukan konsep melalui pemecahan masalah.

Teori pemrosesan informasi Gagne sesuai dengan pembelajaran inkuiri, bahwa inti dari berpikir yang baik adalah kemampuan untuk memecahkan masalah. Dasar dari pemecahan masalah adalah kemampuan untuk belajar dalam situasi proses berpikir sehingga teori pemrosesan informasi sesuai dengan pembelajaran inkuiri (Trianto, 2007).

\section{Hasil Belajar Ranah Psikomotorik}

Hasil analisis ada tidaknya perbedaan hasil dari penerapan pembelajaran InSTAD (Inquiry-STAD) dan Inkuiri Terbimbing (Guided Inquiry) terhadap hasil belajar biologi ranah afektif menggunakan uji $t$ (Tabel 3).

Tabel 3. Hasil Uji Hipotesis Penerapan pembelajaran InSTAD dan Inkuiri Terbimbing terhadap Hasil Belajar Psikomotorik

\begin{tabular}{llllll}
$\begin{array}{l}\text { Hasil } \\
\text { Belajar }\end{array}$ & $\mathbf{t}$ & df & Sig & $\mathbf{t}_{(\mathbf{0 . 5}, 62}$ & $\begin{array}{l}\text { Keputus } \\
\text { an Uji }\end{array}$ \\
\hline $\begin{array}{l}\text { Psikomo- } \\
\text { torik }\end{array}$ & 2.613 & 61 & 0.011 & 1.999 & $\begin{array}{l}\mathrm{H}_{0} \\
\text { ditolak }\end{array}$ \\
\hline
\end{tabular}

Hasil keputusan uji (sig) $<0,050$ dan nilai $t_{\text {hitung }}>\mathrm{t}_{(\alpha, \mathrm{df})}$ sehingga $\mathrm{H}_{0}$ ditolak, hal ini berarti perolehan rata-rata nilai psikomotorik antara kelompok eksperimen 1 dengan kelompok eksperimen 2 berbeda nyata. Kelompok eksperimen 1 dan eksperimen 2 memiliki signifikansi rata-rata nilai psikomotorik. Rata-rata nilai psikomotorik siswa kelompok eksperimen 2 lebih tinggi daripada siswa kelompok eksperimen 1. Berdasarkan perbedaan nilai rata-rata tersebut dapat diketahui bahwa hasil belajar biologi siswa pada ranah psikomotorik dengan penerapan pembelajaran Inkuiri Terbimbing (Guided Inquiry) lebih baik dibandingkan 
dengan penerapan pembelajaran Inquiry STAD (InSTAD).

Hasil belajar ranah psikomotor berkenaan dengan keterampilan atau kemampuan bertindak setelah siswa menerima pengalaman belajar tertentu. Hasil belajar psikomotor ditunjukkan dengan keterampilan manual yang terlihat pada siswa dalam kegiatan fisik. Salah satu di antaranya adalah terampil melakukan kegiatan eksperimen pada materi pelajaran keanekaragaman hayati. Penilaian hasil belajar ranah psikomotorik diperoleh melalui lembar observasi. Teori belajar penemuan Jerome Bruner sesuai dengan pembelajaran inkuiri melalui kegiatan eksperimen siswa, maka pembelajaran akan bermakna karena siswa yang memiliki pengalaman dan melakukan eksperimen untuk menemukan prinsip dan konsep sendiri (Dahar, 1989).

Berdasarkan hasil uji hipotesis diketahui bahwa terdapat perbedaan yang signifikan antara pembelajaran InSTAD dan inkuiri terbimbing pada hasil belajar biologi siswa ranah psikomotorik. Nilai rata-rata psikomotorik kelas eksperimen 2 dengan penerapan pembelajaran inkuiri terbimbing lebih tinggi yaitu 88,32 dengan ketuntasan siswa mencapai $100 \%$ dibandingkan dengan kelas eksperimen 1 melalui penerapan pembelajaran InSTAD dengan nilai rata-rata kelas yaitu 82,66 dan ketuntasan siswa sebanyak $87,5 \%$ siswa (28 siswa). Hal ini disebabkan karena pada pembelajaran inkuiri terbimbing di kelas eksperimen 2 dengan materi keanekaragaman hayati lebih memberikan kesempatan kepada siswa untuk lebih aktif secara fisik karena siswa bekerja secara individu.

Penerapan pembelajaran InSTAD maupun inkuiri terbimbing sama-sama melibatkan siswa ke dalam kegiatan eksperimen. Hal ini didukung dengan pernyataan Nugroho (2012) yang menyatakan bahwa pembelajaran inkuiri merupakan pembelajaran yang langkahnya siswa merumuskan masalah, mendesain eksperi-men, mengumpulkan dan menganalisis data sampai mengambil keputusan sendiri.

Pada kelas eksperimen 2 dengan penerapan pembelajaran inkuiri terbimbing, guru lebih banyak memberikan bimbingan terhadap kegiatan siswa dibandingkan pada kelas eksperimen 1 dengan penerapan pembelajaran InSTAD. Pembelajaran InSTAD guru lebih banyak memberikan kesempatan kepada siswa untuk berdiskusi dengan kelompoknya.

Kegiatan eksperimen dalam kelas eksperimen 1 dengan penerapan pembelajaran InSTAD dan kelas eksperimen 2 dengan penerapan pembelajaran inkuiri terbimbing 
dapat melatih keterampilan motorik dan keterampilan proses sains siswa melalui kegiatan eksperimen, yaitu kegiatan menyusun suatu perencanaan eksperimen untuk melaksanakan praktikum keanekaragaman hayati secara sederhana. Penelitian yang dilakukan di SMA Negeri Gondangrejo menunjukkan $87,5 \%$ siswa telah tuntas dengan penerapan pembelajaran InSTAD dan $100 \%$ siswa telah tuntas dengan penerapan pembelajaran inkuiri terbimbing pada ranah psikomotorik dalam materi pelajaran keanekaragaman hayati. Berdasarkan persentase jumlah siswa yang telah mencapai ketuntasan tersebut terlihat bahwa pembelajaran inkuiri terbimbing menunjukkan hasil yang lebih baik dibandingkan dengan pembelajaran InSTAD pada penilaian ranah psikomotorik.

\section{Kesimpulan}

Berdasarkan hasil penelitian tentang perbedaan hasil dari penerapan pembelajaran InSTAD dan Inkuiri Terbimbing terhadap hasil belajar biologi siswa disimpulkan sebagai berikut:

1. Tidak terdapat perbedaan hasil dari penerapan pembelajaran InSTAD dan Inkuiri Terbimbing terhadap hasil belajar biologi ranah kognitif siswa kelas $\mathrm{X}$ SMA Negeri Gondangrejo Tahun Pelajaran 2012 / 2013.
2. Terdapat perbedaan hasil dari penerapan pembelajaran InSTAD dan Inkuiri Terbimbing terhadap hasil belajar biologi ranah afektif dan psikomotorik siswa kelas X SMA Negeri Gondangrejo Tahun Pelajaran 2012 / 2013.

\section{Daftar Pustaka}

Abdelraheem dan Asan, A. 2006. The Effectiveness of Inquiry-Based Technology Enhaced Collaboration Learning Environment. International Journal of Technology in Teaching and Learning, 2 (2), 65-87

Adeyemi, I and Merry, O. 2009. Assessment in Nigerian School: a Counselor's viewpoint. Edo Journal of Counseling. 2(1):2425.

Amien, M. 1987. Mengajar Ilmu Pengetahuan Alam (IPA) dengan Menggunakan Metode Discovery dan Inquiry. Jakarta: Depdikbud Dirjen Dikti Proyek Pengembangn Lembaga Pendidikan Tenaga Kependidikan.

Crawford, B. A. 2007. Learning to Teach Science as Inquiry in the Rough and Tumble of Practice. Journal of Research in Science Teaching. Vol. 44( 4): 613-642 (2007)

Dahar, R.W. 1989. Teori-Teori Belajar. Jakarta: Erlangga

Hanafiah dan Suhana C. 2009. Konsep Strategi Pembelajaran. Bandung: PT Rofika Aditama

Hanson, D. M. 2005. Designing Process Oriented Guided - Inquiry Activities. Reprinted with permission from "Faculty Guidebook - A Comprehensive Tool for Improving Faculty Performance" Pasific Crest. Stony Brook; Stony Brook University

Nugroho, S. 2012. Pembelajaran IPA dengan Metode Inkuiri Terbimbing Menggunakan 
Laboratorium Riil dan Virtuil Ditinjau dari Kemampuan Memori dan Gaya Belajar Siswa. Jurnal Inkuiri ISSN: 2252-7893, Vol 1(3): 235-244

Poedjiadi, A. 2007. Sains Teknologi Masyarakat Model Pembelajaran Kontekstual Bermuatan Nilai. Bandung: PT. Rosdakarya.

Prayitno, B. A. 2010. Potensi Pembelajaran Biologi Inkuiri Dopadu Kooperatif Dalam Pemberdayaan Berpikir dan Keterampilan Proses Pada Siswa Under Achievment. Proceeding Seminar Sains" Optimalisasi Sains Untuk Memberdayakan Manusia", (hlm.677689). Surabaya: Universitas Negeri Surabaya

Prayitno, B. A. 2011. Pengembangan Perangkat Pembelajaran IPA Biologi SMP Berbasis Inkuiri Terbimbing dipadu Kooperatif STAD serta Pengaruhnya terhadap Kemampuan Berpikir Tingkat Tinggi, Metakognisi, dan Keterampilan Proses Sains pada Siswa Berkemampuan Akademik Atas dan Bawah. (Disertasi tidak dipublikasikan: Universitas Negeri Malang, Malang)

Rustaman, N. Y. (2005). Perkembangan Penelitian Pembelajaran Berbasis Inkuiri dalam Pendidikan Sains. Makalah dipresentasikan dalam Seminar Nasional II Himpunan Ikatan Sarjada dan Pemerhati Pendidikan IPA Idonesia Bekerjasama dengan FPMIPA. Universitas Pendidikan Indonesia, Bandung, 22-23 Juli

Sidiq, Y (2012). Pengaruh Strategi Pembelajaran Inkuiri- STAD (INSTAD) terhadap Keterampilan Proses Sains dan Hasil Belajar Biologi Siswa SMA Batik 1 Surakarta Tahun Pelajaran 2011/2012. (Skripsi Tidak dipublikasikan: FKIP Universitas Sebelas Maret, Surakarta)

Sudjana, N. 2010. Penilaian Hasil Proses Belajar Mengajar. Bandung: PT.Remaja Rosdakarya
Slavin, R. E. 2005. Cooperative Learning: Teori, Riset dan Praktik. Terj. Nurulita. Bandung: Nusa Media

Trianto. 2007. Model-Model Pembelajaran Inovatif Berorientasi Kontruktivistik. Jakarta : Prestasi Pustaka Publisher.

Wulanningsih, S. 2012. Pengaruh Model Pembelajaran Inkuiri Terbimbing Terhadap Keterampilan Proses Sains Ditinjau Dari Kemampuan Akademik Siswa SMA Negeri 5 Surakarta. (Skripsi S1 Tidak dipublikasikan: FKIP Universitas Sebelas Maret Surakarta)

Yager dan Ackay. 2010. The Advantages of an Inquiry Approach for Science Instruction in Middle Grades. Journal of School Science and mathematic, 110 (1): 3-1 
